\title{
Sociale integratie en het kijken naar nieuwsprogramma's als determinanten voor het wisselen van politieke partijkeuze in de periode I994-2006
}

\author{
Fransje Smits \& Niels Spierings ${ }^{1}$
}

\section{Summary}

Social integration and news program watching as determinants of vote switching between 1994-2006

This study examines determinants of vote switching behaviour in the Netherlands in the period 1994-2006. Hypotheses about the influence of social integration and television watching behaviour are tested. By using the Dutch Parliamentary Electoral Studies, we examine whether these factors have an influence on the chance to switch party between two consecutive national parliamentary elections. We find support for some of the hypotheses derived from social integration theory. People living in more urbanized areas and people who have another religious affiliation than their parents switch more often, while it does not matter whether a person differs from his/her parents with respect to occupational class. Our hypothesis about the influence of television watching behaviour is supported: people who watch newscasts more often have a higher chance of switching.

\section{Inleiding}

Het percentage mensen dat bij twee opeenvolgende verkiezingen op verschillende politieke partijen stemt, is in veel westerse democratieën de laatste decennia gestegen (Andeweg \& Irwin, 1993; Dalton \& Wattenberg, 2000; Drummond, 2006). Klaarblijkelijk zijn mensen minder sterk aan een bepaalde partij gebonden zodat het voor nieuwe partijen (partijen die zichzelf nog niet bewezen hebben en partijen met vaak onervaren politici) mogelijk wordt voet aan de grond te krijgen. Een grotere bereidheid van het electoraat om van partijvoorkeur te veranderen maakt ook grote veranderingen in de zetelaantallen van gevestigde partijen moge- 
Figuur 1 Aantal zetels dat bij de Tweede Kamer verkiezingen van de afgelopen decennia van partij wisselde en de zetelaantallen van de drie traditionele partijen

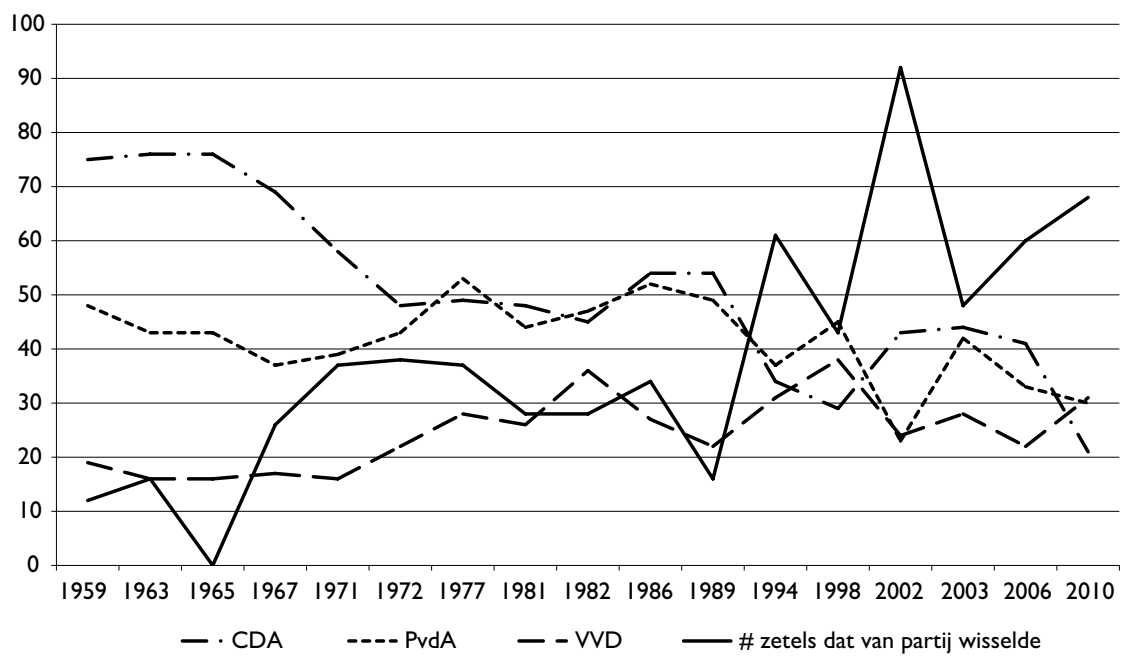

Partijen die later zijn opgegaan in één fusiepartij, beschouwen we van meet af aan al als één partij. Een wissel tussen de KVP, de ARP en de CHU bijvoorbeeld wordt dus ook vóór 1977 niet als wissel beschouwd, evenals een wissel tussen RPF en GPV vóór 2002. Wanneer een zetel van de ene naar de andere partij gaat, is het aantal verwisselde zetels in de figuur $\mathrm{I}$.

BRON: Kiesraad

lijk. Kortom, een toenemend percentage wisselende kiezers kan leiden tot meer politieke instabiliteit.

Ook in Nederland heeft er een dergelijke ontwikkeling plaatsgevonden. In figuur 1 presenteren we voor alle Tweede Kamerverkiezingen van de laatste vijf decennia hoeveel van de 150 zetels van partij wisselden. Ook laat de figuur de aantallen zetels van de drie traditionele partijen (CDA, PvdA en VVD, samen altijd goed voor de meerderheid van de stemmen) over de jaren zien.

Over de gehele linie zien we een toename in het aantal zetels dat van partij wisselt. Met name springen de veranderingen die zich in 2002 ten opzichte van 1998 voordeden eruit. Een groot deel van de mensen die in 2002 op een andere partij stemde dan in 1998, stemde in 2002 op een partij (LPF) waarvan de lijsttrekker en naamgever (Pim Fortuyn) een paar dagen voor de verkiezingen werd vermoord. Ook in de omliggende jaren is het aantal wisselaars niettemin groter dan in eerdere jaren. De drie andere lijnen in de figuur laten zien dat de drie traditionele partijen terrein hebben verloren. Verder zien we sinds 1994 stijgingen en dalingen in zetelaantallen die een halve eeuw geleden slechts over meerdere verkiezingen hebben plaatsgevonden. 
Een andere illustratie van hetzelfde fenomeen is het feit dat in het eerste decennium van de 21ste eeuw veel nieuwe politieke partijen groot zijn geworden. In 2002 deed de LPF voor het eerst mee aan de Tweede Kamerverkiezingen en kreeg meteen 26 van de 150 zetels. In 2006 deed de PVV voor het eerst mee en kreeg er meteen negen. In de tweede helft van de twintigste eeuw kwam het niet voor dat nieuwe partijen meteen bij de eerste verkiezingen waaraan ze deelnamen zoveel zetels haalden. In die periode gebeurde het drie keer dat een nieuwe politieke partij meer dan vijf zetels kreeg: acht voor DS'70 in 1971, zeven voor D66 in 1967 en zes voor de AOV in 1994. In peilingen is de mogelijkheid om als nieuwe partij populair te worden zelfs nog duidelijker zichtbaar (Van der Meer, van Elsas, Lubbe \& Van der Brug, 2012). ${ }^{2}$

Deze grote verschuivingen op het macroniveau (netto-volatiliteit) zijn natuurlijk alleen mogelijk wanneer veel mensen van stemvoorkeur veranderen (bruto-volatiliteit). Omdat in verkiezingsuitslagen mensen met een tegengestelde wissel tegen elkaar wegvallen, is het voor het beeld van de veranderlijkheid van kiezers van groot belang naar individueel wisselgedrag te kijken. Cijfers van Van der Kolk (2000) aangevuld met eigen berekeningen geven het volgende beeld van het aantal mensen dat de afgelopen decennia van partijvoorkeur wisselde.

Inderdaad is er een toename in het aantal wisselaars zichtbaar. Weer springen de verkiezingen van 2002, toen Pim Fortuyn werd vermoord, eruit. Bij deze verkiezingen wisselde bijna de helft van de kiezers van partij. Ook wanneer we alle partijen die issues rondom migranten tot hun een van hun belangrijkste agendapunten maakten (CD, LPF, Fortuyn, DeConservatieven.nl, PVV, EénNL, Partij voor Nederland, Trots op Nederland) als één beweging of partij beschouwen (en dus het wisselen daartussen niet als wisselen, maar als stabiliteit zien), zien we een toename in het aantal wisselaars over de jaren.

Vanwege de geschetste ontwikkelingen zijn verkiezingscampagnes geïntensiveerd, is de politieke stabiliteit afgenomen, is het vormen van coalities moeilijker geworden en lijken mensen in vergelijking tot de tijd van de verzuiling meer vrijheid te hebben in het maken van hun keuze. Er is een grote behoefte aan verklaringen voor deze veranderingen in het Nederlandse politieke landschap (De Beus, 2008; De Groot, 2010; Heutink, 2010; Kranenburg, 2003; NU.nl, 2010b; Schuyt, 2003; Vlasblom, 2008; Vlasblom, 2009; de Volkskrant, 2010).

Ondanks de grote maatschappelijke impact die toenemende volatiliteit dus kan hebben, zijn er slechts enkele studies naar de determinanten ervan verricht (Bybee, McLeod, Luetscher \& Garramone, 1981; Van der Kolk, 2000; Van der Meer et al., 2012; Söderlund, 2008; Zelle, 1995). Terwijl er wel veel onderzoek is verricht naar ontzuiling (Andeweg \& Irwin, 2005; Thurlings, 1971) en veranderende politieke scheidslijnen 
Figuur 2 Het percentage mensen dat van partijkeuze veranderde tussen twee opeenvolgende verkiezingen, als percentage van het aantal mensen dat bij twee opeenvolgende verkiezingen een stem uitbracht

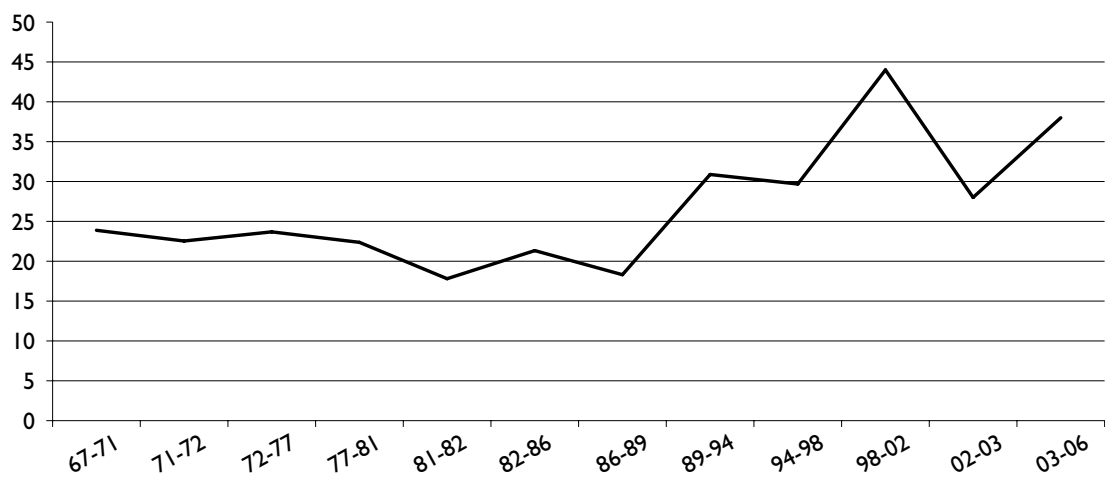

BRON:Van der Kolk (2000) presenteerde percentages wisselaars tot en met '94-'98 en wij berekenden ze aan de hand van Nationaal KiezersOnderzoeken behorende bij de verkiezingen van 1994, 1998, 2002, 2003 en 2006 vanaf '89-'94. De percentages die we voor '89-'94 en voor '94-'98 berekenden, zijn dezelfde als die gepresenteerd door Van der Kolk.

(Brooks, Nieuwbeerta \& Manza, 2006; de Graaf, Jansen \& Need, 2011) in Nederland, is onlangs pas de eerste multivariate studie naar wisselende kiezers verschenen (Van der Meer et al., 2012). Dit terwijl er door het extreem proportionele kiesstelsel met een zeer lage kiesdrempel gemakkelijk politieke verschuivingen plaatsvinden. Mair (2008) laat zien dat de Nederlandse verkiezingsuitslagen inderdaad de veranderlijkste van West-Europa zijn. Vooral de periode waarop wij ons focussen wordt, zoals we al hebben gezien, gekenmerkt door veel politieke verschuivingen. Een eerste manier waarop we in wetenschappelijke zin bijdragen is dus door een nauwelijks onderzochte maar belangrijke casus te onderzoeken: Nederland tussen 1998 en 2006. De eerdere multivariate studie naar wisselgedrag in Nederland, die van Van der Meer et al. (2012), onderzocht determinanten van wisselende partijvoorkeuren van leden van het ÉenVandaag Opiniepanel in de periode tussen de verkiezingen van 2006 en 2010.

Ten tweede dragen we met ons verklaringsmodel bij aan de bestaande kennis. We bestuderen de invloeden van het kijken naar televisie (meer specifiek naar nieuwsprogramma's) en een drietal indicatoren van sociale integratie. Twee eerdere studies hebben het effect van sociale integratie onderzocht. De studie naar Nederland in de periode 20062010 van Van der Meer e.a. (2012) bevat echter andere indicatoren dan deze studie. De auteur van de tweede studie (Zelle, 1995) beweert wel het effect van sociale integratie op volatiliteit in Duitsland te bekijken, maar wij zijn van mening dat de gebruikte indicatoren, opleidingsniveau en 
beroepsstatus, maar weinig over sociale integratie zeggen. Ook gebruikt hij ondervragingsjaar als indicator voor sociale integratie. Omdat jaar echter over zoveel dingen tegelijkertijd iets zegt, kan sociale integratie beter inhoudelijk worden gemeten (De Graaf, 1988; Rodgers, 1982). Daarbij is een ecologische (Robinson, 1950) of aggregative (Susser, 1973) fout niet uit te sluiten: dat zowel sociale integratie en stabiliteit van politieke partijvoorkeur afnemen over de jaren betekent niet dat het de minst sociaal geïntegreerden zijn die wisselen van partijvoorkeur. Wij richten ons op effecten van de mate van homogeniteit van sociale netwerken waarin mensen zich begeven. Geen van beide studies keek naar televisieconsumptie. Naar wij weten, is er slechts één onderzoek geweest naar het effect van televisieconsumptie op indicatoren van volatiliteit (in dit geval een onstabiele partijbinding) (Bybee et al., 1981). Een uniek kenmerk van het medium televisie is dat het de mogelijkheid biedt om een volledig beeld van politici te krijgen. Niet elk programma op de televisie draagt natuurlijk bij aan dit beeld. Om die reden kijken we alleen naar het effect van het kijken naar nieuwsprogramma's. Niet alleen de standpunten van politici kunnen via dit medium duidelijk worden, hetzelfde geldt voor hun hele voorkomen. In de tussentijd gebeurt dit natuurlijk ook veel via andere media. Maar ten tijde van het laatste survey dat we in dit onderzoek meenemen, werd er nog veel meer televisie gekeken dan gebruik werd gemaakt van een computer (150 versus 58 minuten per dag (SPOT, 2006)) en op de computer filmpjes bekijken gebeurde nog heel weinig. In de paragraaf theorieën en hypothesen zullen we beargumenteren dat het wisselen van partijkeuze een logisch gevolg van televisie kijken kan zijn.

De keuze voor deze twee perspectieven komt niet zozeer voort uit het feit dat we denken dat het de sterkst denkbare voorspellers voor het wisselen van partijkeuze zijn, maar uit het idee dat ze in staat zouden kunnen zijn de toename in het wisselen van partijkeuze over de tijd te verklaren. Behalve veranderingen aan de kant van de politieke partijen, zien wij geen andere factoren die daar een verklaring voor zouden kunnen bieden. Sociale integratie en het kijken naar nieuwsprogramma's zijn fysieke en structurele kenmerken die door duidelijk externe factoren zoals technologische ontwikkeling over de tijd zijn veranderd. Daarom zouden ze bevredigende verklaringen kunnen bieden voor de verandering in onze afhankelijke variabele over de tijd. Op deze manier kunnen we dus inzicht verkrijgen in hoe de richting waarin onze maatschappij zich beweegt van invloed is op onder andere de politieke stabiliteit. Sociale integratie nam de laatste decennia af (Breedveld, Van den Broek, De Haan, Harms, Huysmans \& Van Ingen, 2006; Coleman, 1990; Feld, 1981; Feld, 1984; De Hart, Knol, Maas-de Waal \& Roes, 2002; McPherson, Smith-Lovin \& Brashears, 2006; Scheepers \& Janssen, 2001; Völker, Flap \& Mollenhorst, 2009; SCP, 
1998) en de hoeveelheid tijd dat mensen televisie kijken toe (Aguiar \& Hurst, 2007; Breedveld et al., 2006). Helaas ligt het verklaren van de trend niet binnen onze mogelijkheden. We zijn slechts in staat ons op een korte periode te richten. Een periode bovendien waarin het percentage wisselaars niet toeneemt, maar enkel sterk fluctueert (zie figuur 2). Wel kan onze studie aanknopingspunten bieden voor het verklaren van de trend, zoals we verder bespreken in de conclusie.

We zullen in dit onderzoek een aantal cross-secties van het Nationaal KiezersOnderzoek gebruiken om de volgende onderzoeksvraag te beantwoorden: In welke mate zijn sociale integratie en het kijken naar nieuwsprogramma's determinanten van het wisselen van partijkeuze van stemmers in Nederland in de periode 1998-2006?

\section{Theorieën en hypothesen}

\section{I Sociale integratie}

Volgens de sociale-integratietheorie is iemands politieke partijvoorkeur afhankelijk van de politieke partijvoorkeuren van mensen in zijn of haar sociale omgeving (Durkheim, 1951 [1897]; Heath, Jowell \& Curtice, 1985; Lazarsfeld, Berelson \& Gaudget, 1944). Onderzoeksresultaten laten inderdaad zien dat de sociale omgeving een effect heeft (Nieuwbeerta \& Flap, 2000). Wanneer de sociale beïnvloeding bij mensen echter niet homogeen is, omdat ze een heterogeen en weinig gesloten sociaal netwerk hebben, hebben ze een grotere kans op veranderlijkheid. Het hebben van een heterogeen sociaal netwerk en het hebben van contacten met mensen die elkaar niet kennen, impliceert namelijk een zwakke integratie in één bepaalde groep. Hoe meer iemand omgaat met mensen uit één bepaalde groep, hoe eenduidiger de invloed op het gebied van politieke partijvoorkeur en hoe meer vaststaand zijn of haar eigen politieke partijvoorkeur zal zijn. Voor mensen die minder sterk in één bepaalde groep geïntegreerd zijn, is het minder duidelijk waarop te stemmen. Ondanks de bevindingen van Van der Meer et al. (2012) die het idee van een stabiliserende werking van sociale integratie niet ondersteunen, verwachten wij op basis van het zojuist beschreven mechanisme dat mensen die minder sterk in één bepaalde groep zijn geïntegreerd een grotere wisselkans hebben.

Allereerst verwachten we dat er een positief effect is van urbanisatie op de kans van partijkeuze te wisselen (H1). In steden is het aantal potentiele sociale contacten binnen een bepaalde afstand groter, zijn sociale banden minder intensief, zijn mensen minder georiënteerd op de familie en zijn sociale netwerken minder gesloten en homogeen (Curtis White \& Guest, 2003; Höllinger \& Haller, 1990). Daarnaast is verhuismobiliteit hoog in 
steden (CBS, 2011). Mensen die in steden wonen, hebben dus een lage kans om al lang in dezelfde buurt te wonen en hetzelfde geldt voor hun buurtgenoten. Stedelingen hebben daardoor een kleinere kans om al lang contacten in hun leefomgeving te hebben en om contact te hebben met mensen uit hun leefomgeving die elkaar ook kennen. Samenvattend ontstaan in steden moeilijker stabiele gemeenschappen. Daarom is het voor stedelingen minder duidelijk op welke partij te stemmen en op basis van sociale-integratietheorie kan verwacht worden dat dat tot een grotere wisselkans leidt. Desondanks vonden Van der Meer et al. (2012) geen verschillen tussen mensen woonachtig in grote steden, kleine steden en dorpen.

We hebben beargumenteerd dat mensen met een wat politieke partijvoorkeur betreft heterogene sociale omgeving een grotere kans hebben om van partijkeuze te wisselen. Twee achtergrondkenmerken die van groot belang voor politieke partijvoorkeur zijn gebleken, zijn beroepsstatus en religie (Brooks et al., 2006; Jansen, 2011). Belangrijke factoren in de sociale omgeving van mensen zijn hun ouders. Daarom verwachten we dat mensen die een andere beroepsklasse (H2) en religie (H3) hebben dan hun ouders, een grotere kans hebben om van partijkeuze te wisselen. Mensen die mobiel zijn wat betreft beroepsklasse of religie, hebben een meer heterogene sociale omgeving. Sociale netwerken passen zich namelijk langzaam aan en daarom zullen mobiele mensen vaak contacten binnen zowel hun herkomstklasse en -religie, en bestemmingsklasse en -religie hebben (Abramson, 1972; Nieuwbeerta, De Graaf \& Ultee, 2000). De religiositeit en beroepsklasse van mensen worden natuurlijk vooral in een bepaalde levensfase, grofweg tussen het 15de en 30ste levensjaar, vastgelegd. Dit betekent dat politieke partijvoorkeur waarschijnlijk ook vooral in die levensfase instabiel is. Wij gaan echter niet in op deze specificatie en bestuderen het effect voor alle leeftijden tegelijkertijd.

\subsection{Het kijken naar nieuwsprogramma's}

Het kijken naar nieuwsprogramma's kan op verschillende manieren resulteren in een hogere kans om van partijkeuze te wisselen. Allereerst kunnen mensen door naar nieuwsprogramma's te kijken meer gefocust raken op de persoonlijkheid en het charisma van politici. Weber (1964 [1922]) beschreef de overgang van gezag gebaseerd op traditie en gezag gebaseerd op iemands persoonlijke kwaliteiten naar gezag gebaseerd op de positie die de leider bekleedt. Door de komst van de televisie kregen mensen de mogelijkheid om een volledig beeld van het voorkomen van politici te krijgen en mogelijk werd gezag hierdoor meer persoonlijk (Ansolabehere, Behr \& Iyengar, 1991; Castells, 1997; Elchardus, 2002). Het werd mogelijk om het voorkomen en het charisma van politici mee te 
nemen in de keuze voor een bepaalde partij. Recentelijk zijn er inderdaad verschillende wetenschappers geweest die suggereerden dat dit een factor zou kunnen zijn die een rol speelt in het keuzeproces (Anker, 1995; Van der Brug \& Mughan, 2007; Husbands, 1998; Lubbers, Gijsberts \& Scheepers, 2002). Wij stellen dat de kans op het wisselen van partijkeuze groter is wanneer mensen hun partijkeuze baseren op het charisma van politici. Mensen kunnen namelijk in het ene jaar een politicus van de ene partij het aantrekkelijkst vinden qua persoonlijkheid en voorkomen, en in het andere jaar een politicus van een andere partij. ${ }^{3}$ De 'poppetjes' van partijen veranderen sneller dan de standpunten. Het kijken naar televisie en met name het kijken naar programma's waarin politiek aan bod komt, zoals nieuwsprogramma's, is cruciaal om een idee te krijgen van de persoonlijkheid en het voorkomen van politici. Een tweede mechanisme is dat televisie mensen in contact brengt met andere meningen en het een inkijk geeft in verschillende sociale omgevingen. Ook dit kan de politieke partijvoorkeur van mensen veranderen. We verwachten dat mensen die meer naar nieuwsprogramma's kijken, een hogere kans hebben om van partijkeuze te veranderen (H4). Bybee et al. (1981) hebben het effect van de hoeveelheid tijd dat mensen televisie kijken op items gerelateerd aan een onstabiele partijbinding bekeken. Voor het kijken naar programma's die zich focussen op politiek, vonden ze een effect in de door ons verwachte richting en voor het kijken naar amusementsprogramma's vonden ze het omgekeerde.

\section{Data en metingen}

\section{I Data}

Voor onze analysen maakten we gebruik van het Nationaal KiezersOnderzoek (NKO) van 1998 (Aarts, Van der Kolk \& Kamp, 1999), 2002/2003 (Irwin, Van Holsteyn \& Den Ridder, 2005) en 2006 (Aarts, Van der Kolk, Rosema \& Schmeets, 2007; Van der Worp, 2008). Elk van deze surveys is nagenoeg representatief voor de Nederlandse bevolking. Met name zijn de surveys representatief voor de groep stemmers, de mensen waarin wij geïnteresseerd zijn dus. ${ }^{4}$ Voor de modellen met onafhankelijke variabelen die in meer dan één survey beschikbaar waren, hebben we de bestanden samengevoegd. NKO2002/2003 bevat een panelstructuur. We zorgden er echter voor dat één en hetzelfde individu niet meer dan eens wordt meegenomen in de analyses. Het totaal aantal cases in deze surveys is 8085 . Na de selectie van de voor ons relevante cases (zie volgende paragraaf), blijven er 5828 over. 


\subsection{Afhankelijke variabele en methode}

Respondenten is gevraagd op welke partij ze stemden bij de laatste en bij de voorlaatste parlementaire verkiezingen. Mensen wordt dus gevraagd hun stemgedrag van jaren geleden te rapporteren. Dit zou voor een onderschatting van het percentage wisselaars kunnen zorgen (Van der Kolk, 2000; Van der Meer et al., 2012). Mensen zien zichzelf namelijk graag als stabiel (Jaspers, Lubbers \& De Graaf, 2009). Omdat een deel van de data een panelstructuur kent, is het mogelijk om na te gaan in hoeverre respondenten over de tijd consistent zijn in het rapporteren van eerder stemgedrag. 94 procent van de mensen bleek in de eerste ronde van het survey hetzelfde antwoord over hun partijvoorkeur bij de verkiezingen van 2002 te geven als in de tweede ronde van het survey (gehouden rond de verkiezingen van 22 januari 2003).

Een voorwaarde om bij twee opeenvolgende verkiezingen op dezelfde partij te kunnen stemmen, is dat de partij waarop de eerste keer gestemd werd, de tweede keer ook meedoet. Om deze reden namen we slechts respondenten mee die bij de eerste verkiezingen stemden op een partij die bij de tweede verkiezingen ook meedeed. Anders was de respondent natuurlijk gedwongen om van partijkeuze te veranderen. Het zijn vooral partijen die weinig zetels haalden die bij de volgende verkiezingen niet meer op de kieslijst verschenen. Hierdoor vielen op basis van dit criterium nog geen dertig respondenten af. Deze mensen stemden bijvoorbeeld op de CD of Nederland Mobiel in 1998 of op Leefbaar Nederland in 2003. We hebben er bewust voor gekozen om kiezers op nieuwe partijen niet te verwijderen. Zij hadden namelijk wel de keuze om stabiel te blijven. Mensen die bij de eerste verkiezingen stemden op een partij die bij de tweede verkiezingen was gefuseerd en bij de tweede verkiezingen op die fusiepartij stemden, zien we niet als wisselaars.

Een tweede criterium is dat mensen bij allebei de opeenvolgende verkiezingen een stem uit hebben gebracht. Dit betekent tevens dat we alleen mensen meenemen die ten tijde van de eerste verkiezingen ten minste 18 jaar oud waren. Een wissel van niet stemmen naar wel stemmen (en vice versa) is een ander soort wissel dan een wissel van de ene naar de andere partij (Söderlund, 2008). Wat ons betreft zouden predictoren voor het wisselen tussen wel en niet participeren dus apart bepaald moeten worden. Niet-stemmers konden geen geschikte partij vinden tussen de in dat jaar deelnemende partijen of het was voor hen dat jaar in praktische zin niet mogelijk een stem uit te brengen. Bij de wisselaars tussen wel en niet stemmen kan de onderliggende partijvoorkeur dus ook hetzelfde zijn gebleven. ${ }^{5}$ Wanneer we mensen die bij één van beide verkiezingen niet hebben gestemd ook mee zouden nemen, zou elk model ongeveer $12 \%$ meer cases bevatten.

De afhankelijke variabele is dichotoom: mensen die wisselden van 
partijkeuze tussen twee opeenvolgende verkiezingen scoren ' 1 ' en mensen die twee keer op dezelfde partij stemden scoren ' 0 '. Vanwege deze dichotomie maken we gebruik van logistische-regressieanalyse. We presenteren drie modellen: één met naast de controlevariabelen urbanisatie en het kijken naar nieuwsprogramma's, één met naast de controlevariabelen urbanisatie, het kijken naar nieuwsprogramma's en anders zijn dan je ouders wat betreft religie, en één met naast de controlevariabelen urbanisatie, het kijken naar nieuwsprogramma's en het anders zijn dan je ouders wat betreft beroepsklasse. We willen zoveel mogelijk informatie gebruiken en daarom maken we niet slechts gebruik van het survey waarin alle kenmerken te meten zijn (NKO 1998).

\subsection{Onafhankelijke variabelen}

Urbanisatie: voor elke respondent in de data is de urbanisatiegraad van de gemeente waarin hij of zij woont toegevoegd. Deze variabele heeft de volgende vijf categorieën: 0 = niet urbaan: 1-499 adressen $/ \mathrm{km}^{2}, 1=$ nauwelijks urbaan: 500-999 adressen $/ \mathrm{km}^{2}, 2=$ licht urbaan: 1000-1499 adressen $/ \mathrm{km}^{2}, 3$ = sterk urbaan: 1500-2499 adressen $/ \mathrm{km}^{2}, 4=$ zeer sterk urbaan: meer dan 2500 adressen $/ \mathrm{km}^{2}$. In de gepresenteerde modellen is dit als continue variabele opgenomen. We rapporteren echter ook hoe het effect van urbanisatie eruit ziet wanneer we er dummy's voor opnemen.

Andere beroepsklasse dan ouders: Dit valt alleen vast te stellen in het survey van 1998. Een respondent scoort een ' 0 ' wanneer hij/zij tot dezelfde EGP-klasse als zijn/haar ouders behoort. We gebruiken de EGP92-classificatie met zeven categorieën (Erikson, Goldthorpe \& Portocarero, 1979). We nemen de hoogste van vaders en moeders beroepsklasse en de hoogste beroepsklasse van respondent en eventuele partner (alleen wanneer ze samenwonen). De reden dat we de klasse van de partner meenemen in het geval dat die hoger is, is dat binnen huishoudens arbeidscarrières vaak op elkaar worden afgestemd. Voordat we de hoogste score nemen, vullen we voor arbeidsongeschikten en gepensioneerden de EGP-score van het vorige beroep in. Dit lijkt ons namelijk de passendste score voor mensen die geen score hebben omdat hun loopbaan onderbroken of beëindigd is vanwege arbeidsongeschiktheid of het bereiken van de pensioengerechtigde leeftijd. Bij werkloosheid ligt dat wat ons betreft anders en daarom creëerden we voor werkloze ouders, respondenten en partners een extra (achtste) EGP-categorie. De kleine groep studenten in de data heeft, tenzij ze een partner met een geldige score hebben, geen geldige score op deze variabele.

Andere religie dan ouders: Dit valt niet vast te stellen in het survey van 2006. Respondenten is gevraagd met welke religie ze zijn opgevoed en 
welke religie ze nu aanhangen. Vier groepen werden onderscheiden: protestanten, katholieken, anderszins religieuze mensen en niet-religieuze mensen. Wanneer een respondent zich nu nog tot de religie rekent waarmee hij/zij is opgevoed, scoort hij/zij een ' 0 '. Wanneer de respondent zich nu tot een andere groep rekent, scoort hij/zij een ' 1 '.

Kijken naar nieuwsprogramma's: Respondenten is gevraagd hoe vaak ze naar RTL Nieuws en hoe vaak ze naar het NOS journaal kijken. Er waren steeds vier antwoordcategorieën. We hercodeerden de items zo dat een ' 0 ' betekent dat de respondent minder dan eens per week naar het programma kijkt en een '3' dat hij/zij er (bijna) dagelijks naar kijkt. Vervolgens nemen we het gemiddelde voor de twee programma's.

Controlevariabelen: We controleren voor leeftijd, opleidingsniveau, geslacht en ondervragingsjaar. Leeftijd varieert van 18 tot 99 en nemen

Tabel 1 Beschrijvende statistieken per surveyjaar voor hen die op alle variabelen een geldige score hebben

\begin{tabular}{|c|c|c|c|c|c|c|c|c|}
\hline \multirow[b]{2}{*}{ Variabele } & \multicolumn{4}{|c|}{$1998(N=1368)$} & \multicolumn{4}{|c|}{$2002(N=1301)$} \\
\hline & Min. & Max. & Gemiddelde & SD & Min. & Max. & Gemiddelde & SD \\
\hline Wissel partijkeuze & 0 & 1 & 0,316 & & 0 & 1 & 0,404 & \\
\hline Urbanisatie & 0 & 4 & 1,990 & 1,312 & 0 & 4 & 2,082 & 1,319 \\
\hline $\begin{array}{l}\text { Andere religiositeit dan } \\
\text { ouders }\end{array}$ & 0 & 1 & 0,340 & & 0 & 1 & 0,350 & \\
\hline $\begin{array}{l}\text { Andere beroepsklasse dan } \\
\text { ouders }\end{array}$ & 0 & 1 & 0,810 & & & & & \\
\hline Kijken nieuwsprogramma's & 0 & 3 & 1,914 & 0,764 & 0 & 3 & 2,083 & 0,716 \\
\hline Leeftijd & 20 & 90 & 47,287 & 15,448 & 22 & 97 & 51,654 & 14,855 \\
\hline Basisonderwijs & 0 & 1 & 0,134 & & 0 & 1 & 0,067 & \\
\hline Lbo & 0 & 1 & 0,162 & & 0 & 1 & 0,114 & \\
\hline Mavo/havo/vwo & 0 & 1 & 0,177 & & 0 & 1 & 0,157 & \\
\hline Mbo & 0 & 1 & 0,264 & & 0 & 1 & 0,294 & \\
\hline Hbo/Universitair & 0 & 1 & 0,263 & & 0 & 1 & 0,368 & \\
\hline \multirow[t]{3}{*}{ Man (vs.Vrouw) } & 0 & 1 & 0,500 & & 0 & 1 & 0,483 & \\
\hline & \multicolumn{4}{|c|}{$2003(N=1140)$} & \multicolumn{4}{|c|}{$2006(N=1826)$} \\
\hline & Min. & Max. & Gemiddelde & SD & Min. & Max. & Gemiddelde & SD \\
\hline Wissel partijkeuze & 0 & 1 & 0,318 & & 0 & 1 & 0,378 & \\
\hline Urbanisatie & 0 & 4 & 1,950 & 1,420 & 0 & 4 & 1,990 & 1,286 \\
\hline $\begin{array}{l}\text { Andere religiositeit dan } \\
\text { ouders }\end{array}$ & 0 & 1 & 0,374 & & & & & \\
\hline Kijken nieuwsprogramma's & 0 & 3 & 2,082 & 0,755 & 0 & 3 & 1,925 & 0,839 \\
\hline Leeftijd & 18 & 99 & 48,071 & 14,357 & 22 & 91 & 49,465 & 15,598 \\
\hline Basisonderwijs & 0 & 1 & 0,058 & & 0 & I & 0,053 & \\
\hline Lbo & 0 & I & 0,106 & & 0 & 1 & 0,160 & \\
\hline Mavo/havo/vwo & 0 & I & 0,156 & & 0 & I & 0,085 & \\
\hline Mbo & 0 & I & 0,344 & & 0 & 1 & 0,409 & \\
\hline Hbo/Universitair & 0 & 1 & 0,336 & & 0 & 1 & 0,292 & \\
\hline Man (vs.Vrouw) & 0 & 1 & 0,457 & & 0 & I & 0,493 & \\
\hline
\end{tabular}

BRON: Nationaal KiezersOnderzoek, 1998-2006 
we op als intervalvariabele. Voor opleidingsniveau nemen we de volgende dummy's op: basisonderwijs, lager beroepsonderwijs, mavo/havo/ vwo, mbo, hbo/universitair. Mannen scoren een ' 1 ' en vrouwen een ' 0 '. Ondervragingsjaar nemen we op in dummy's.

Respondenten met ontbrekende scores op één of meer variabelen zijn verwijderd. Er bleven 5635 respondenten over. In tabel 1 presenteren we de beschrijvende statistieken van alle variabelen voor alle surveys apart.

\section{Resultaten}

Voordat we de resultaten van de multivariate analysen presenteren, presenteren we enkele bivariate resultaten in tabel 2 .

Wat betreft de relatie tussen de mate van urbanisatie van de gemeente waarin een respondent woont en zijn/haar kans om van stemkeuze te veranderen, zien we dat mensen woonachtig in gemeenten behorende tot de twee meest urbane categorieën het meest wisselen. De relatie is grotendeels lineair. De groep woonachtig in de meest urbane gemeenten zit wat betreft wisselkans tussen de gemeenten met scores ' 2 ' en ' 3 ' in. Niettemin is de Kendalls taucorrelatiecoëfficiënt tussen urbanisatie en de kans om van partijkeuze te wisselen significant en in de in hypothese één verwachte richting $(0,054$ bij $p=0,000)$.

Het verschil tussen mensen die wel en niet anders zijn dan hun ouders wat betreft beroepsklasse is klein: 31,3 versus $32,7 \%$ wisselaars. Dit verschil is niet in de in hypothese twee verwachte richting. Het ver-

Tabel 2 Percentages wisselaars voor verschillende categorieën

\begin{tabular}{llcl}
\hline Variabele & Categorie & $\begin{array}{l}\text { Aantal mensen in deze } \\
\text { categorie }\end{array}$ & $\begin{array}{l}\text { Percentage van hen dat } \\
\text { wisselde }\end{array}$ \\
\hline Urbanisatie $=$ & 0 (= niet urbaan) & 967 & 31,5 \\
& $\mathrm{I}$ & 1295 & 34,2 \\
& 2 & 1197 & 34,8 \\
& 3 & 1460 & 39,2 \\
& 4 (= zeer sterk urbaan) & 909 & 37,5 \\
\hline Andere beroepsklasse & nee & 260 & 32,7 \\
dan ouders = & ja & 1124 & 31,3 \\
\hline Andere religie dan & nee & 2491 & 32,9 \\
ouders $=$ & ja & 1361 & 37,6 \\
\hline Kijken & 0,0 (= nooit) & 169 & 34,9 \\
Nieuwsprogramma's $=$ & 0,5 & 170 & 38,8 \\
& 1,0 & 451 & 33,7 \\
& 1,5 & 1648 & 33,5 \\
& 2,0 & 1149 & 36,4 \\
& 2,5 & $77 \mid$ & 35,4 \\
& $3,0(=$ (bijna) dagelijks) & 1434 & 38,4 \\
\hline
\end{tabular}

BRON: Nationaal KiezersOnderzoek, 1998-2006 
schil tussen mensen die wel en niet anders zijn dan hun ouders wat betreft religie is groter en wel in de verwachte richting. Mensen die anders zijn dan hun ouders wat betreft religie (vanwege kerkverlating, bekering of het wisselen van religieuze denominatie) wisselen in bijna $38 \%$ van de gevallen, terwijl mensen die niet anders zijn dan hun ouders wat betreft religie in slechts 33\% van de gevallen wisselen. Dit verschil is significant bij $p=0,003$.

De relatie tussen het kijken naar nieuwsprogramma's en het wisselen van partijkeuze blijkt volgens de bivariate resultaten in tabel 2 niet lineair te zijn. Toch is er sprake van een significante Kendalls taucorrelatiecoëfficiënt in de in hypothese vier verwachte richting: 0,034 bij $p=0,018$. Wanneer we de mensen met een score van op zijn hoogst ' 1 ' samenvoegen (deze drie categorieën bevatten relatief weinig mensen), zien we een meer lineaire relatie. De volgorde van veel naar weinig wisselaars is dan: mensen met score ' 1,5 ', de samengevoegde categorie $(0,0$, $0,5$ en 1,0$), 2,5,2,0,3,0$.

In tabel 3 presenteren we de resultaten van de multivariate logistische-regressieanalysen.

We leidden drie hypothesen uit de sociale-integratietheorie af. Allereerst hypothetiseerden we een positief effect van urbanisatie (H1). In tabel 2 hebben we al gezien dat zonder te controleren voor andere

Tabel 3 Logistische-regressieanalysen van het wisselen van partijkeuze

\begin{tabular}{|c|c|c|c|c|c|c|c|c|c|}
\hline & \multicolumn{3}{|c|}{ Model I:'98/'02/’03/'06 } & \multicolumn{3}{|c|}{ Model 2:'98/'02/’03 } & \multicolumn{3}{|c|}{ Model 3:'98 } \\
\hline & $B$ & & SE & B & & SE & B & & SE \\
\hline Intercept & $-0,114$ & & 0,181 & $-0,466$ & $*$ & 0,220 & $-0,014$ & & 0,382 \\
\hline Urbanisatie & 0,075 & $* *$ & 0,021 & 0,053 & $*$ & 0,026 & 0,018 & & 0,045 \\
\hline Andere beroepsklasse dan ouders & & & & & & & $-0,098$ & & 0,149 \\
\hline Andere religie dan ouders & & & & 0,181 & $*$ & 0,072 & & & \\
\hline Kijken nieuwsprogramma's & 0,110 & $* *$ & 0,037 & 0,132 & *** & 0,048 & 0,042 & & 0,080 \\
\hline Leeftijd & $-0,020$ & $* *$ & 0,002 & $-0,017$ & *** & 0,003 & $-0,019$ & $* *$ & 0,004 \\
\hline \multicolumn{10}{|l|}{ Opleiding (basisonderwijs = ref) } \\
\hline Lager beroepsonderwijs & $-0,161$ & & 0,132 & 0,071 & & 0,158 & 0,166 & & 0,235 \\
\hline Mavo/havo/vwo & 0,099 & & $0,|3|$ & 0,247 & & 0,150 & 0,025 & & 0,223 \\
\hline Mbo & $-0,18 \mid$ & & 0,123 & $-0,004$ & & 0,147 & $-0,016$ & & 0,231 \\
\hline Hbo/universitair & $-0,254$ & $*$ & 0,124 & $-0,101$ & & 0,145 & 0,112 & & 0,225 \\
\hline Man & 0,017 & & 0,057 & 0,044 & & 0,070 & 0,038 & & 0,119 \\
\hline \multicolumn{10}{|l|}{ Ondervragingsjaar (1998 = ref) } \\
\hline 2002 & 0,488 & $* *$ & 0,084 & 0,458 & ** & 0,085 & & & \\
\hline 2003 & 0,045 & & 0,088 & 0,019 & & 0,089 & & & \\
\hline 2006 & 0,367 & $* *$ & 0,078 & & & & & & \\
\hline$N$ & 5644 & & & 3809 & & & $|37|$ & & \\
\hline Nagelkerke $R^{2}$ & 0,037 & & & 0,036 & & & 0,025 & & \\
\hline
\end{tabular}

*** $p<0,01$ (tweezijdig)

$* p<0,05$ (tweezijdig)

BRON: Nationaal KiezersOnderzoek, 1998-2006 
zaken, er inderdaad een positief verband met het wisselen van partijkeuze bestaat, maar ook onder controle van de overige onafhankelijke variabelen blijkt de samenhang positief te zijn. De samenhang tussen urbanisatie en het wisselen van partijkeuze is echter alleen in de eerste twee modellen (met substantieel meer respondenten dan het derde) significant. In het eerste model is het effect van urbanisatie het grootst en daar zien we dat als iemands score op de urbanisatiemaat met één toeneemt (op een schaal van 0-4), de kans om van partijkeuze te wisselen versus de kans om dat niet te doen met bijna acht procent $\left(\left(e^{0,075}-1\right)^{*} 100\right)$ toeneemt. Wanneer we urbanisatie in dummy's opnemen, zien we dat het de samenhang met de kans om te wisselen van partijkeuze grotendeels lineair is. Met uitzondering van de mensen uit de meest urbane categorie (die tussen de middencategorie en de op één na meest urbane categorie in blijken te zitten), wordt de kans om te wisselen van partijkeuze groter met elke toename in urbanisatie.

Ten tweede hypothetiseerden we dat mensen die een andere beroepsklasse hebben dan hun ouders een grotere kans hebben om van partijkeuze te wisselen (H2). We hebben al gezien dat er bivariaat nauwelijks een verschil bestaat tussen mensen die wel en niet anders zijn dan hun ouders wat betreft beroepsklasse. En ook onder controle van een reeks andere onafhankelijke variabelen zien we geen significant andere kansen om te wisselen van partijkeuze (model 3). Deze hypothese moet dus worden verworpen. Het effect halveert en blijft insignificant wanneer we dummy's voor eigen beroepsklasse aan het model toevoegen. Deze categorische variabele heeft dezelfde categorieën als genoemd bij de operationalisatie van de variabele die meet of er een verschil met de ouders is.

We verwachtten ook dat mensen die anders zijn dan hun ouders wat betreft religiositeit een hogere kans hebben om van partijkeuze te wisselen (H3). Voor deze hypothese wordt wel ondersteuning gevonden. Voor mensen die anders zijn dan hun ouders wat betreft religie is de kans om van partijkeuze te wisselen versus de kans om dat niet te doen bijna $20 \%$ hoger dan voor anderen. Dit effect halveert en is niet meer significant wanneer we dummy's voor eigen religie aan het model toevoegen. Deze categorische variabele heeft dezelfde vier categorieën als genoemd bij de operationalisatie van de variabele die meet of er een verschil met de ouders is. Additionele analysen wijzen uit dat de afvalligen de grootste switchkans hebben, gevolgd door de mensen die niet religieus zijn opgevoed en nu ook seculier zijn. Het effect van anders zijn dan je ouders wat betreft religiositeit is niet meer significant wanneer alle variabelen tegelijkertijd worden opgenomen.

Vervolgens hypothetiseerden we dat er een positief effect van het kijken naar nieuwsprogramma's op de kans om te wisselen van partijkeuze 
zou zijn (H4). Deze verwachting wordt bevestigd in de eerste twee modellen. In het tweede model is de samenhang tussen het kijken naar nieuwsprogramma's en het wisselen van partijkeuze het grootst. Wanneer de score van mensen op deze variabele één hoger is (dus bijvoorbeeld 3-4 keer in plaats van 1-2 keer per week), neemt de kans om van partijkeuze te wisselen versus de kans om dat niet te doen in dit model met meer dan $14 \%$ toe. $^{6}$

Het effect van de eerste controlevariabele die we opnamen, leeftijd, is in elk model significant negatief bij $p<0,01$. In het tweede model is de samenhang met het wisselen van partijkeuze het kleinst. In dit model zien we dat met elk jaar ouder, de kans om van partijkeuze te wisselen versus de kans om dat niet te doen met 1,7\% afneemt.

Wat betreft het effect van opleidingsniveau zien we in model 1 verschillen die significant zijn bij op zijn minst $p=0,05$ tussen mensen met op zijn hoogst een mavo/havo/vwo-diploma en mensen met lager beroepsonderwijs, een mbo-diploma en een hbo- of universitair diploma en tussen mensen met enkel basisonderwijs en mensen met een hbo- of universitaire opleiding. De volgorde van de kleinste kans om te wisselen van partijkeuze naar de grootste kans om dat te doen: hbo'ers/academici, mbo'ers, lbo'ers, mavo/havo/vwo'ers. In model 2 hebben de mensen met maximaal mavo/havo/vwo een significant grotere kans om te wisselen van partijkeuze dan de mensen met maximaal mbo en de mensen met hbo/universiteit. In model 3 wijken geen van alle opleidingscategorieën significant van elkaar af.

Het verschil tussen mannen en vrouwen is in geen van de modellen significant. In het model met alle surveyjaren (model 1) is de kans om te wisselen van partijkeuze significant lager in 1998 dan in 2002 en 2006. Additionele analysen wijzen uit dat ook in 2003 de kans om te wisselen lager was dan in 2002 en in 2006. Dit beeld is vergelijkbaar met het in de introductie geschetste bivariate beeld. In het tweede model is het verschil tussen 1998 en 2002 en het verschil tussen 2002 en 2003 significant.

Om de verschillende modellen met elkaar te kunnen vergelijken, hebben we model 1 ook over enkel respondenten die in de modellen 2 en 3 meegenomen worden geschat. Wanneer we model 1 schatten voor de respondenten uit model 2, blijken de hypothesen over de effecten van urbanisatie en het kijken naar nieuwsprogramma's nog altijd bevestigd te worden. Wanneer we model 1 schatten voor de respondenten uit model 3, zijn deze effecten niet meer significant. Ook al zijn modellen 2 en 3 niet in elkaar genest, we hebben ook model 2 voor de respondenten uit model 3 geschat. Geen enkele van de factoren waarover we hypothetiseerden, blijkt er dan nog toe te doen voor de kans om van partijkeuze te switchen. 
Ook al is ontevredenheid met de partij waarop de vorige keer gestemd is een noodzakelijkheid voor wisselgedrag en dus een weinig bevredigende verklaring, we hebben gekeken wat opname doet met de resultaten. We maten dit met vragen over hoe sympathiek respondenten de verschillende politieke partijen vinden. We kenden iedere respondent een relatieve score toe: hoe sympathiek vindt men de partij waarop de vorige keer gestemd is in vergelijking tot de andere partijen. Weinig verrassend laten deze additionele modellen laten zien dat ontevredenheid een sterke predictor voor het wisselen van partijkeuze is (het effect is altijd significant bij $\mathrm{p}<0,01$ ). Het opnemen van ontevredenheid verandert de resultaten niet substantieel. Meestal worden de significanties en de B-coëfficiënten wat kleiner. Het effect van anders zijn dan je ouders wat betreft religie wordt juist substantieel groter. Klaarblijkelijk worden de verbanden tussen onze X-en en het wisselen van partijkeuze amper gemedieerd door ontevredenheid.

Zoals besproken in de introductie zijn er het afgelopen decennium verschillende anti-immigrantenpartijen opgekomen. De anti-immigrantenpartij die meedeed aan de verkiezingen van 1998, de CD, kreeg enkel $0,6 \%$ van de stemmen terwijl de anti-immigrantenpartij die in 2002 meedeed 17\% kreeg. In $2003 \mathrm{kreeg}$ deze partij slechts 5,7\% van de stemmen en een andere anti-immigrantenpartij kreeg 0,03\%. In 2006 kreeg een nieuwe anti-immigrantenpartij 5,89\% van de stemmen en de drie andere anti-immigrantenpartijen die dat jaar deelnamen, kregen tezamen minder dan $1 \%$. Vanwege deze ontwikkelingen hebben we de modellen opnieuw geschat waarbij we alle anti-immigrantenpartijen als één beschouwen (wat concreet betekent dat het wisselen tussen deze partijen niet als wisselen wordt gezien) en analysen waarbij we de aanname doen dat mensen met een negatieve houding ten aanzien van immigranten vóór 2002 geen acceptabele optie hadden om op te stemmen en in 2002 dus gedwongen waren te switchen (wat concreet betekent dat we mensen die in 2002 op de LPF stemden verwijderen). Hierdoor kunnen we te weten komen in hoeverre de resultaten beïnvloed worden door de groep mensen die in 2002 LPF stemden en op andere anti-immigrantenpartijen daarna. Zoals in de datasectie beschreven, zijn mensen die bij één van twee opeenvolgende verkiezingen niet stemden sowieso niet opgenomen in deze studie. In modellen waarbij we wisselen tussen antiimmigrantenpartijen onderling niet als wisselen zien, blijven alle eerder getrokken conclusies over de hypothesen overeind. In modellen waarbij we de mensen die in 2002 LPF stemden verwijderen, is er één substantiële verandering ten opzichte van de conclusies op basis van de gepresenteerde modellen: het effect van urbanisatie verliest in model 2 zijn significantie. ${ }^{7}$ 


\section{Conclusie en discussie}

In dit onderzoek hebben we gekeken naar de invloeden die sociale integratie en het kijken naar nieuwsprogramma's op de kans om van partijkeuze te wisselen hebben. In de inleiding beargumenteerden we dat een toename in het aantal wisselaars politieke stabiliteit ondermijnt. De casus die we bestudeerden - Nederland in de periode 1994-2006 - is een belangrijke en is nog niet eerder bestudeerd. Ook droegen we bij aan de literatuur door te kijken naar determinanten die nog niet eerder (adequaat) zijn bestudeerd. We hebben beargumenteerd waarom sociale integratie en televisieconsumptie belangrijk zijn als bevredigende verklaringen voor het toegenomen wisselen van partijkeuze. De effecten van deze potentiele determinanten hebben we bekeken in de Nationaal KiezersOnderzoeken voor de Tweede Kamerverkiezingen van 1998, 2002, 2003 en 2006. Sommige van onze resultaten ondersteunden de hypothesen, andere falsificeerden ze.

We vinden gedeeltelijk ondersteuning voor sociale integratie als verklaring voor het wisselen van stemkeuze. We beargumenteerden dat sociale netwerken in meer urbane gebieden minder hecht zijn en daarom verwachtten we een positief effect van urbanisatie op de kans om van partijkeuze te wisselen. De data lieten zien dat in het Nederland van 1998-2006 stedelingen inderdaad vaker wisselen. Verder leidden we van sociale-integratietheorie af dat mensen die een andere beroepsklasse of religie hebben dan hun ouders, een grotere kans hebben om van partij te wisselen. Alleen voor het anders zijn wat betreft religie vinden we een aanwijzing dat het de wisselkans positief beïnvloedt. Er is geen verschil in de kans om te wisselen tussen mensen die wel en mensen die niet anders zijn dan hun ouders wat betreft beroepsklasse.

Mensen die meer naar nieuwsprogramma's kijken, blijken inderdaad een grotere kans te hebben om van partijkeuze te wisselen. Dit ondersteunt het idee dat als mensen zich meer laten leiden door de persoonlijkheid en het uiterlijk van politici (waarvoor het noodzakelijk is om televisie te kijken) en als ze meer in aanraking komen met andere meningen (wat een logisch gevolg is van televisie kijken), ze een grotere kans hebben om van partijkeuze te wisselen. Ook is het mogelijk dat het verband tussen het kijken naar nieuwsprogramma's en het wisselen van partijkeuze (deels) voortkomt uit een effect van het laatste op het eerste: wanneer iemand al twijfelt over zijn of haar partijkeuze, kan het zijn dat hij/zij meer naar nieuwsprogramma's gaat kijken om zijn/ haar keuze verder te bepalen. Het feit dat we in een aanvullende analyse geen verband tussen ontevredenheid met de partij waarop vorige keer gestemd is en het kijken naar nieuwsprogramma's vonden en het feit dat het verband tussen het kijken naar nieuwsprogramma's en wisselen van partijkeuze niet afneemt na toevoeging van ontevredenheid aan het 
model, maakt deze omgekeerde causaliteit echter niet zo waarschijnlijk. Wel is niet uit te sluiten dat mensen om zelfde redenen naar nieuws kijken en wisselen van partijkeuze. Een voorbeeld van zo'n reden is het openstaan voor verschillende meningen.

In de inleiding beargumenteerden we dat we ondanks het feit dat we niet in staat zijn de trend naar meer wisselaars te verklaren, hiervoor wellicht wel aanknopingspunten kunnen vinden. Wanneer we een effect van een bepaald kenmerk op de kans om van partijkeuze te wisselen vinden en we weten dat de mate waarin dit kenmerk in de samenleving aanwezig is, is veranderd over de jaren, wordt het waarschijnlijker dat dit kenmerk een (gedeeltelijke) verklaring voor de trend kan bieden. Dit geldt inderdaad voor urbanisatie, voor anders zijn dan je ouders wat betreft religieuze overtuiging en voor het kijken naar nieuwsprogramma's. Deze factoren zijn namelijk van positieve invloed op de kans om te wisselen en de mate waarin deze factoren in de samenleving aanwezig zijn, zijn toegenomen door de jaren heen (Aguiar \& Hurst, 2007; Breedveld et al., 2006; De Graaf, Need \& Ultee 2004; Te Grotenhuis \& Scheepers 2001; World Development Indicators 2012). Een andere potentiële belangrijke verklaring voor de toename in het aantal wisselaars is het feit dat politieke partijen wat betreft hun standpunten meer op elkaar zijn gaan lijken. Ook al is de neiging om qua standpunten zo dicht mogelijk tegen andere partijen aan te gaan zitten, veel groter in tweepartijensystemen, ook voor Nederland is aangetoond dat partijen wat betreft standpunten meer op elkaar zijn gaan lijken (De Graaf et al., 2012 nings \& Keman, 2008). Wij moedigen vervolgonderzoek naar de beschrijving en verklaring van de trend aan.

Ook moedigen we onderzoek naar de interactie tussen factoren die vooral de bereidheid om te wisselen lijken te vergroten en factoren die vooral de motieven om te wisselen lijken te vergroten aan. Mensen die bereid zijn om van partijkeuze te wisselen hebben daar immers niet altijd redenen voor. Een minder hecht sociaal netwerk lijkt bijvoorbeeld vooral de bereidheid om te wisselen te vergroten, niet zozeer de motivatie om het ook daadwerkelijk te doen. Mensen hebben ook een reden nodig om hun gedrag te veranderen. Ontevredenheid met de partij waarop de vorige keer gestemd is, is duidelijk een reden voor gedragsverandering. Deze combinatie van bereidheid en motivatie kan mogelijkerwijs een verklaring bieden voor de ontwikkelingen die we in de figuren in de inleiding zagen. De sociale integratie in een samenleving verandert natuurlijk maar erg langzaam, terwijl ontevredenheid snel kan toeslaan. In de figuren zagen we een over de gehele linie langzaam toenemend aantal wisselaars, maar binnen die langzaam stijgende lijn zagen we ook sterke kortetermijnschommelingen. Misschien kan een dergelijk patroon worden verklaard door een combinatie van de aanwezigheid van bereidheid en motivatie. 
Tot slot zou vervolgonderzoek een verder onderscheid kunnen maken tussen effecten van opwaartse en neerwaartse mobiliteit en tussen effecten van of mensen anders zijn dan hun ouders wat betreft religie vanwege afvalligheid, bekering of het wisselen van denominatie. Ook is de ene wissel van partijkeuze de andere niet. Zoals Van der Meer et al. (2012) laten zien, wordt er vooral tussen blokken van partijen gewisseld. Wellicht zouden we dan ook andere effecten van de door ons bestudeerde verklaringen vinden, wanneer wisselen tussen partijen die dicht bij elkaar staan niet als wisselen wordt gezien.

\section{Noten}

1. Beide auteurs hebben in gelijke mate bijgedragen aan de totstandkoming van dit artikel. Beide schrijven een proefschrift aan de Radboud Universiteit Nijmegen. Fransje Smits (f.smits@maw.ru.nl) doet dat bij de afdeling Sociologie en Niels Spierings (n.spierings@fm.ru.nl) bij de afdelingen Politicologie en Economie.

2. Volgens verschillende peilingen zou de PVV bij verkiezingen aan het eind van 2004 24-29 zetels hebben gekregen (TNS NIPO, 2004a; TNS NIPO, 2004b; Algemeen Dagblad, 2004; de Jong, 2009). Bij de Tweede Kamerverkiezingen van 2010 kreeg de PVV 24 zetels. Een maand na deze verkiezingen zou de PVV 35 zetels hebben gekregen (NU.nl, 2010a). Het in 2007 opgerichte TON kreeg bij een peiling in oktober 200729 zetels (TNS NIPO, 2007), en bij peilingen in mei-juni 2008 24-25 zetels (Politieke Barometer, 2008; Het Parool, 2008). Bij de verkiezingen van 2010 kreeg TON geen enkele zetel (Kiesraad, 2010).

3. Voorbeelden zijn de grote toename in de steun voor de PvdA nadat Job Cohen werd gepresenteerd als potentiele lijsttrekker (TNS NIPO, 2010; Politieke Barometer, 2010) en de steun voor de SP die sterk wisselde met het af- en aantreden van Jan Marijnissen, Agnes Kant en Emile Roemer (De Pers, 2010; Peil.nl, 2012).

4. Het ernstigste probleem is de ondervertegenwoordiging van de niet-stemmers in $2002 / 2003$. Ondervertegenwoordiging van niet-stemmers is in zijn algemeen een probleem in kiezerssurveys. In deze studie worden mensen die bij minimaal één van twee opeenvolgende verkiezingen niet stemmen echter niet meegenomen. Hierdoor heeft het gebrek aan representativiteit waar op dit punt sprake van is, geen gevolgen voor de resultaten van onze studie. De steekproeven zijn representatief wat betreft de partijkeuzen van de stemmers. Voor meer informatie over de representativiteit van de NKO's: zie de genoemde codeboeken.

5. Wel is het opkomstpercentage over de jaren heen veranderd. Het daalde van 78,6 in 1994 naar 73,4 in 1998 om vervolgens naar 79,1 in 2002, 80,0 in 2003 en 80,4 in 2006 te stijgen. Het daalde weer naar ongeveer het niveau van 1998 in $2010(75,4)$. Mensen die bij één van beide verkiezingen niet stemden, stemden bij de verkiezingen waar ze wel stemden vaak PvdA, SP, LPF en PVV. Het is echter niet zo dat de LPF in 2002 slechts mensen trok die bij de vorige verkiezingen niet stemden: $19,3 \%$ van de LPF-stemmers in 2002 bracht in 1998 geen stem uit. Voor de PVV in 2006 is dit percentage 22,3 .

6. In model 3 zien we dat de effecten van urbanisatie en het kijken naar nieuwsprogramma's niet alleen niet meer significant zijn, maar ook een stuk kleiner dan in de eerdere modellen. Dit zou mogelijk gelegen kunnen zijn in dat er in 1998 wel eens sprake zou kunnen zijn geweest van een ander type switch dan in 
de latere jaren die we meenemen in ons onderzoek. Er was een grote tevredenheid over Paars en waar normaal gesproken regeringspartijen verliezen, kregen ze er in 1998 in totaal vijf zetels bij en verloor het CDA nog eens extra. Mogelijk switchten bijvoorbeeld traditioneel op het CDA stemmende plattelandsbewoners naar PvdA, VVD of D66.

7. We hebben in een bivariate analyse gezien dat mensen die niet in Nederland zijn geboren, niet anders zijn wat betreft wisselkans dan mensen die wel in Nederland zijn geboren. Ook wanneer we een migrantvariabele opnemen in de modellen zoals we die presenteren, maakt het voor de kans om te wisselen niet uit of iemand migrant is of niet. Ook verandert opname niets aan de effecten van de andere variabelen.

8. De Graaf et al. laten zien dat partijen de laatste decennia meer op elkaar zijn gaan lijken als het gaat om economische issues. Voor culturele issues is dit echter niet het geval. De auteurs laten zien dat iemands houdingen ten aanzien van economische issues belangrijker zijn geworden voor zijn/haar partijvoorkeur.

\section{Literatuur}

Aarts, K., H. van der Kolk \& M. Kamp (1999). Dutch parliamentary election study 1998. Amsterdam: Steinmetz Archive/Stichting Kiezersonderzoek Nederland.

Aarts, K., H. van der Kolk, M. Rosema \& H. Schmeets (2007). Dutch parliamentary election study 2006. Data Archiving and Networked Services/ Statistics Netherlands (CBS)/Dutch Electoral Research Foundation (SKON).

Abramson, P.R. (1972). Intergenerational social mobility and partisan choice. American Political Science Review, 66, 1291-1294.

Aguiar, M. \& E. Hurst (2007). Measuring trends in leisure: The allocation of time over five decades. Quarterly Journal of Economics, 122 (3), 9691006.

Algemeen Dagblad (2004). Wilders zakt iets terug. December 6.

Andeweg, R. \& G. Irwin (1993). Dutch government and politics. London: MacMillan.

Andeweg, R.B. \& G.A. Irwin (2005). Governance and politics of the Netherlands. Houndmills/New York: Palgrave MacMillan.

Anker, H. (1995). Kiezers, politici en partijkeuze. In J.J.M. Van Holsteyn \& B. Niemöller (eds.), De Nederlandse kiezer 1994. Leiden: DSWO Press.

Ansolabehere, S., R. Behr \& S. Iyengar (1991). Mass media and elections: An overview. American Politics Quarterly, 19, 109-139.

Beus, J. de (2008). Globaliseringsvrees. Column in televisieprogramma Buitenhof op 22 juni.

Breedveld, K., A. van den Broek, J. de Haan, L. Harms, F. Huysmans \& E. van Ingen (2006). De tijd als spiegel. Hoe Nederlanders hun tijd besteden. Den Haag: SCP. 
Brooks, C., P. Nieuwbeerta \& J. Manza (2006). Cleavage-based voting behavior in cross-national perspective: Evidence from six postwar democracies. Social Science Research, 35, 88-128.

Brug, W. van der \& A. Mughan (2007). Charisma, leader effects and support for right-wing populist parties. Party Politics, 13:1, 29-51.

Bybee, C.R., J.M. McLeod, W.D. Luetcher \& G. Garramone (1981). Mass communication and voter volatility. Public Opinion Quarterly, 45, 69-90.

Castells, M. (1997). The power of identity. Oxford: Blackwell Publishers, Inc. CBS (2011). Statline. Online beschikbaar op www.cbs.nl.

Coleman, J.S. (1990). Foundations of social theory. Cambridge, MA: Harvard University Press.

Curtis White, K.J. \& A.M. Guest (2003). Community lost or transformed? Urbanization and social ties. City \& Community 2, 239-259.

Dalton, R.J. \& M.P. Wattenberg (2000). Parties without partisans: Political change in advanced industrial democracies. Oxford: Oxford University Press.

De Pers (2012). Peiling: CDA zakt verder terug. http://www.depers.nl/ binnenland/462122/CDA-zakt-verder-in-peiling.html, 11 maart.

de Volkskrant (2010). Nieuwe peiling: kiezers wisselvallig in keuze. www. volkskrant.nl, 6 juni.

Drummond, A. J. (2006). Electoral volatility and party decline in Western democracies: 1970-1995. Political Studies, 54 (3), 628-647.

Durkheim, E. (1951). Suicide. New York: Free Press (orig. pub. 1897).

Elchardus, M. (2002). De Dramademocratie. Tielt: Lannoo.

Erikson, R., J.H. Goldthorpe \& L. Portocarero (1979). Intergenerational class mobility in three Western European societies: England, France and Sweden. British Journal of Sociology, 33, 1-34.

Feld, S. (1981). The focused organization of social ties. American Journal of Sociology, 86,5 1015-1053.

Feld, S. (1984). The structured use of personal associates. Social Forces, 62, 3, 640-652.

Graaf, N.D. de (1988). Postmaterialism and the stratification process: An international comparison. Utrecht: ISOR.

Graaf, N.D. de, G. Jansen \& A. Need (2012) (forthcoming). The political evolution of social class and religion: An interpretation for the Netherlands 1971-2006, in: G. Evans \& N. D. de Graaf (eds.), Political choice matters: Examining social and political change in cross-national perspective. Oxford: Oxford University Press.

Graaf, N.D. de, A. Need \& W. Ultee (2004). Leaving the church in the Netherlands: A comprehensive explanation for three empirical regularities. In: Crocket, A. \& O'Leary R. (eds.) Patterns and processes of religious change in modern industrial societies: Europe and the United States. Lewiston: Edwin Mellen Press. Pp. 81-116. 
Groot, M. de (2010). We hebben te weinig schokdempers in het systeem. Interview with Kees Aarts in Data \& Research, June.

Grotenhuis, M. te \& P. Scheepers (2001). Churches in Dutch: Causes of religious disaffiliation in the Netherlands, 1937-1995. Journal for the Scientific Study of Religion, 40, 591-606.

Höllinger, F. \& M. Haller (1990). Kinship and social networks in modern societies: A cross-cultural comparison among seven nations. European Sociological Review, 6, 1030-24

Hart, J. de, F. Knol, C. Maas-De Waal \& T. Roes (2002). Zekere banden. Sociale cohesie, leefbaarheid en veiligheid. Den Haag: SCP.

Heath, A., R. Jowell \& J. Curtice (1985). How Britain votes. Pergamon Press, Oxford.

Het Parool (2008). Verdonk en D66 blijven stijgen. 5 mei.

Heutink, R. (2010). Kiezersgedrag. NRC Handelsblad, 22-28 mei.

Husbands, C. (1998). De Centrumstroming in perspectief: hoe verschillend is Nederland? In J. van Holsteyn \& C. Mudde (eds.), Extreem-rechts in Nederland, pp. 175-192. The Hague: Sdu Uitgevers.

Irwin, G.A., J.J.M. van Holsteyn \& J.M. den Ridder (2005). Dutch parliamentary election study 2002-2003. Amsterdam: Steinmetz Archive/Stichting Kiezersonderzoek Nederland.

Jansen, G. (2011). Social cleavages and political choices. Large-scale comparisons of social class, religion and voting behavior in Western democracies. $\mathrm{PhD}$ thesis, Nijmegen: Department of Sociology/ICS.

Jaspers, E., M. Lubbers \& N.D. de Graaf (2009). Measuring once twice: An evaluation of recalling attitudes in survey research. European Sociological Review, 25 (3), 287-301.

Jong, P.H. de (2009). Wilders in peilingen en in verkiezingsuitslagen. Nederlands Dagblad, 4 september.

Kiesraad (2010). Online beschikbaar op www.kiesraad.nl

Kolk, H. van der (2000). Aarzelende, wisselende en zwevende kiezers, in: J.J.A. Thomassen, C.W.A.M. Aarts \& H. van der Kolk (red.), Politieke veranderingen in Nederland 1971-1998, kiezers en de smalle marges van de politiek, 93-106. Den Haag: SDU.

Kranenburg, M. (2003). De flipperkast-democratie. NRC Handelsblad, 11 januari.

Lazarsfeld, P.F., B. Berelson \& H. Gaudget (1944/1948). The people's choice: How the voter makes up his mind in a presidential campaign. New York: Colombia University Press.

Lubbers, M., M. Gijsberts \& P. Scheepers (2002). Extreme right-wing voting in Western Europe. European Journal of Political Research, 41, 345-378.

Mair, P. (2008). Electoral volatility and the Dutch party system: a comparative perspective. Acta Politica, 43, 235-253.

McPherson, M., L. Smith-Lovin \& M.E. Brashears (2006). Social isolation 
in America. Changes in core discussion networks over two decades. American Sociological Review, 71, 353-75.

Meer, T. van der, E. van Elsas, R. Lubbe \& W. van der Brug (2012). Kieskeurige kiezers. Universiteit van Amsterdam.

Nieuwbeerta, P., N.D. de Graaf \& W. Ultee (2000). Effects of class mobility on class voting in post-war western industrialized countries. European Sociological Review, 16, 327-348.

Nieuwbeerta, P. \& H. Flap (2000). Crosscutting social circles and political choice. Effects of personal network composition on voting behavior in The Netherlands. Social Networks, 22, 313-335.

NU.nl. (2010a). PVV historisch hoog in peiling. www.nu.nl, 18 juli.

NU.nl. (2010b). Electoraat in peilingen nog steeds onstabiel. www.nu.nl, 6 juni.

Peil.nl (2012). Nieuw Haags Peil 22 januari 2012. https://n9.noties.nl/peil. $\mathrm{nl} /$ (bezocht op 22 januari 2012).

Pennings, P. \& H. Keman (2008). The changing landscape of Dutch politics since the 1970s: A comparative exploration. Acta Politica, 43, 154-179.

Politieke Barometer (2008). http://www.politiekebarometer.nl/peilingen. cfm?jaar=2008. Synovate.

Politieke Barometer (2010). http://www.politiekebarometer.nl/peilingen. cfm?jaar=2010. Synovate.

Robinson, W.S. (1950). Ecological correlations and the behavior of individuals. American Sociological Review, 15, 351-357.

Rodgers, W. L. (1982). Estimable functions of age, period, and cohort effects. American Sociological Review, 47, 774-787.

Scheepers, P. \& J. Janssen (2001). Informele aspecten van sociaal kapitaal. Ontwikkelingen in Nederland, 1970-1998. Mens \& Maatschappij, 3, 183201.

Schuyt, K. (2003). Kiezers als stuifzand. de Volkskrant, 15 januari.

Sociaal en Cultureel Planbureau (1998). Sociaal en Cultureel Rapport 1998. Online beschikbaar op http://www.scp.nl/dsresource?objectid=21420 \& type $=$ org

Söderlund, P. (2008). Retrospective voting and electoral volatility: A Nordic perspective. Scandinavian Political Studies, 31, 217-240.

Susser, M. (1973). Causal thinking in the health sciences. London: Oxford University Press.

Thurlings, J.M.G. (1971). De wankele zuil - Nederlandse katholieken tussen assimilatie en pluralism. Nijmegen/Amersfoort.

TNS NIPO (2004a). http://www.tns-nipo.com/pages/nieuws-pers-politiek. asp?file=persvannipo\%5Cpol04_47.htm, bezocht op 12 januari 2010.

TNS NIPO (2004b). http://www.tns-nipo.com/pages/nieuws-pers-politiek. asp?file=persvannipo\%5Cpol04_49.htm, bezocht op 12 januari 2010. 
TNS NIPO (2007). http://www.tns-nipo.com/pages/nieuws-pers-vnipo. asp?file=persvannipo $\backslash$ rtl_trots_op_nederland07.htm, bezocht op 12 januari 2010.

TNS NIPO (2010). http://www.tns-nipo.com/pages/nieuws-pers-politiektk2010.asp?file=persvannipo\pol_pvda_grootste_310310.htm, bezocht op 12 januari 2010.

Vlasblom, D. (2008). Culturele armoede: waarom rechts populisme aanslaat bij laagopgeleide arbeiders. NRC Handelsblad, 21 juni.

Vlasblom, D. (2009). Rechts populisme groeit tegen de recessie in. NRC Handelsblad, 24 maart.

Völker, B., H. Flap \& G. Mollenhorst (2009). Changing places. The influence of meeting places on recruiting friends, pp. 28-48 in Ray May Hsung, Nan Lin \& Ronald Breiger (eds.), Contexts of social capital: Social networks in communities, markets and organizations. Oxford: Routledge.

Weber, M. (1964). The theory of social and economic organization. Glencoe, IL.: Free Press (orig. pub. 1922).

World Development Indicators (2012). Online beschikbaar op http://data. worldbank.org/data-catalog/world-development-indicators.

Worp, J. van der (2008). Documentatierapport NKO (Nationaal Kiezers Onderzoek) 2006V1. Statistics Netherlands (CBS).

Zelle, C. (1995). Social dealignment versus political frustration: Contrasting explanations of the floating vote in Germany. European Journal of Political Research, 27, 319-45.

http://www.spot.nl/pdf_technisch/tabellen_tbo.pdf, bezocht in september 2011.

http://home.fsw.vu.nl/hbg.ganzeboom/ISKO88/index.htm, bezocht in november 2009. 